University of California, Hastings College of the Law UC Hastings Scholarship Repository

Published Scholarship

The Honorable Roger J. Traynor Collection

1965

\title{
The Unguarded Affairs of the Semikempt Mistress
}

Roger J. Traynor

Follow this and additional works at: http://repository.uchastings.edu/traynor_scholarship_pub

\section{Recommended Citation}

Roger J. Traynor, The Unguarded Affairs of the Semikempt Mistress, 113 U. PA. L. REV . 485 (1965).

Available at: http://repository.uchastings.edu/traynor_scholarship_pub/23

This Article is brought to you for free and open access by the The Honorable Roger J. Traynor Collection at UC Hastings Scholarship Repository. It has been accepted for inclusion in Published Scholarship by an authorized administrator of UC Hastings Scholarship Repository. For more information, please contact marcusc@uchastings.edu. 
$7 c / 5$

28 



\title{
THE UNGUARDED AFFAIRS OF
}

\section{THE SEMIKEMPT MISTRESS}

\section{By}

\author{
ROger J. Traynor
}

Reprinted from

University of Pennsyluania Law Review

Philadelphia, Pa., U. S. A.

Volume 113, No. 4, February, 1965

(c) Copyright 1965 by the University of Pennsylvania 



\section{THE UNGUARDED AFFAIRS OF THE SEMIKEMPT MISTRESS *}

\section{Roger J. Traynor $\dagger$}

In 1965 we are ninety years removed from the date of Owen J. Roberts' birth in Philadelphia in 1875 . In 1875 he was only seventyfive years removed from the close of the decade 1790-1800 when Philadelphia was the capital of the country. As a child nurtured in the heart of the early United States, he must have known elders not far removed from the American Revolution. He lived long enough in the twentieth century to know revolutionary changes throughout the world and the portents of more to come. His devotion to the University of Pennsylvania Law School bespeaks his sense of the need for the law to develop as rationally as possible to give reasonable order to the churning times.

In this notably moonstruck century lawyers still give the appearance of being solidly grounded. Who else could so persuasively suggest how free from moonshine they are as they document argument with mundane detail in the light of the midday sun? Who but these unhappy few would be so deadly serious even when they romantically personify their profession as a "Jealous Mistress?" Who but the learned brethren would join in lute songs to her forbidding ancestry

* This article was presented orally as the Owen J. Roberts Memorial Lecture, delivered November 12,1964, under the auspices of the Pennsylvania Chapter of the Order of the Coif and the University of Pennsylvania Law School.

† Chief Justice of the California Supreme Court. A.B. 1923, Ph.D., J.D. 1927, University of California. 
and commanding virtues? Who but the lawyers would set aside Law Days to pledge her their love and their overtime?

For all our sober allegiance, however, we do hardly better than anyone else to see straight the object of our devotion. Clearly she is a venerable image and one of substantial worth. She can at times be of dazzling beauty. She has the beguiling class of age, the patina of many ages, the appearance of one who will survive us all. It is easy to overlook that an idol of such irreproachable clay evinces some frailties when she spirits herself away from her noble base to become a spectral wanderer. In any direction in space or time, she can wander at will. She haunts the obscure trails marked out by ancient pilgrims, where landmarks are sometimes engulfed in rubble, and their eroded inscriptions can be said to mean anything. ${ }^{1}$ She haunts freeways where modern pilgrims speed endlessly whenever they are not stalled, and she is known for compounding the confusion of any collision with lunatic instructions. ${ }^{2}$ She frequently takes off on byways that many a poor pilgrim has never discovered, or has come upon to his woe.

None of us can ever know all that there is to know about her. Nonetheless there is cause to know that whenever she is at large she is not always so kempt as she should be. We fail her as well as ourselves if we fail to direct questions at her now and again when we are within shouting distance. Should we not call her to account for at least her unguarded affairs of wide and disturbing import?

There is one area on which we are fairly knowledgeable. We know the ways of the law in the appellate court, not merely because they are amply reported, but because they are amply and critically reviewed. Scholars inspect the output of the appellate process as if it were dynamite, and they comment exhaustively on innocuous defects as well as on patent dangers. There are law journals enough to train searchlights upon the courts everywhere in the land, and they are quick to note the errant ways of appellate decision from the most righteous sentimentalism to the most wrongheaded standpattism. Hence an appellate opinion must pass muster with scholars as well as with practitioners "on the alert to note any misunderstanding of the

${ }^{1}$ See Traynor, Badlands in an Appellate Judge's Realm of Reason, 7 Utä L. REv. 157 (1960).

2 See Werkman v. Howard Zink Corp., 97 Cal. App. 2d 418, 428-31, 218 P.2d 43, 49-52 (Dist. Ct. App. 1950); FranK, LAW AND THE Modern Mind 181-85 (1949); Cunningham, Instructing Juries, 32 CAL. S.B.J. 127 (1957); Traynor, Fact Skepticism and the Judicial Process, $106 \mathrm{U}$. PA. L. Rev. 635, 637 (1958); Wiehl, Instructing a Jury in Washington, 36 WASH. L. REv. 378 (1961); Winslow, The Instruction Ritual, 13 Hastings L.J. 456 (1962); 1959 Institute for California Judges-Panel Discussion Part III: Instructing the Jury, 47 CALIF. L. REv. 888 (1959); Note, Standard Jury Instructions, 98 U. PA. L. REv. 223 (1949). 
problem, any error in reasoning, any irrelevance in data, any oversight of relevant data, any premature cartography beyond the problem at hand." 3

There is no way of measuring the effect of constant law review critiques on the appellate process. Nevertheless, the increasing reference to them in opinions and briefs indicates that they are carrying increasing weight with judges and lawyers alike. It is no modern judge who still prides himself on some obscurely stated rapport with the reported authorities that in his mind render other learning expendable. It is no modern lawyer who still disdains the critiques, content to rest easy in hard cases with the undemonstrative Shepards of the what-has-been, with all that has been indiscriminately stuffed into the overstuffed concept called authority. There is a pall on the once formidable Confrérie de Chevaliers Pontificaux in the practicing bar given to heeding and speaking no preachments other than what they have practiced.

The fact that it is no longer deemed pedantic, let alone eccentric, for a judge or a lawyer to be caught red-eyed with a law journal evinces rising standards of learning in the profession. Improvements in judicial administration, though far from universal, have encouraged the hope of our saying in time that at least with regard to judicial procedure the law is a zealous housekeeper. Lest we gild the lily-toillately prematurely, however, we do well to remember that even in the most ceremonial of her many domains the force of inertia continues to operate against good housekeeping. For all the scholarly vigil that fosters a relatively well-kept judicial domain, the overall order is marred by large patches of unkemptness. There are still all too many lawyers as well as judges so habituated to the dust-laden air amid creaking gates and accumulated debris as to be insensitive to the need for wholesome renovation.

Moreover, we have yet to resolve the still troubling question that regards not the jealous mistress, who can comport herself tolerably well in court, but what we might describe as the extrinsic bawd. The extrinsic bawd still demands of too many judges in too many states that irrespective of their qualifications they prove themselves popular not only in one popular election but even thereafter in office to minimize the risks of elections to come. ${ }^{4}$ There are well-qualified men who will not enter the lists of such a contest, knowing that they must either compromise the very qualities that make a good judge, notably a dis-

3 Traynor, Comment, in Legal Institutions Today and Tomorrow 48, 52 (1959).

1 See Rosenman, A Better Way To Select Judges, 48 J. Am. Jud. Soc'y 86, 88-89 (1964). 
passionate unconcern with popular fads and fancies, or risk losing the contest to the fad-and-fancy candidate. By luck the populace sometimes gets better than one might expect, or by luck an unlikely choice proves in time worthy of office. But it is no easy matter for such dignitaries that the extrinsic bawd sits on the courthouse steps, biding her time till the next election and promising her favors to whichever ogler is willing to do her bidding. Pessimists have cause to query what profit it the mistress to appear majestic in court if the bawd selects custodians given to excessive indulgence in the currying of popular or powerful favor.

One can respond to the pessimists that all is not lost where so many watchbirds are counteracting the omnipresence of the bawd. At least the appellate judge, whose opinions are not only relentlessly reviewed by scholarly critics, but also critically read by an increasing number of well-educated lawyers, comes to find in the very existence of this alert audience some reassurance of the independence of his office no less than of its responsibility.

The welcome watchbirds of the appellate courts have yet to watch as intently the central domains of the legislatures and the multitudinous strongholds of administrative boards and of private groups who in their own recesses exercise power over their constituents not unlike that of a state. ${ }^{5}$

Why not? What distinguishes these other areas of the law from judicial law that they have escaped vigil as relentless as that on the courts? How has it come about that the journals quick to break out in a swift-rising chorus of woe over the pox on any salient judicial opinion make no such vehement outcry over many an equally poxy nonjudicial dictate that roughens the course of law?

So large an inquiry calls for a series of responses on the various aspects of nonjudicial law to yield the benefits of all points of view. Each is likely to be partial, in the dual sense of one-sided, whatever its range of objectivity, insofar as it conveys the perspective of a particular vantage point. Thus, with relation to the legislative process alone, to say nothing of such a giant spin-off as administrative law, some commentators are advantageously situated to inquire into its origins and evolution, others to focus upon what it produces, and still others to note in detail how effectively it functions. My own reflections, in the nature of preliminary observations rather than final judgments, will confine themselves to the different standards of vigilance for appellate courts and for legislatures, to some indications of

- See Traynor, Better Days in Court for a New Day's Problems, 17 VANd. L. REv. 109, 118-21 (1964). 
rising standards of legislation despite inadequate vigilance, and particularly to the import of statutes that determine or influence the course of judicial procedure and administration.

Given the long predominant role of the judiciary in the development of the law, it is understandable that traditional critics preoccupied themselves with what had been wrought by the established primary developers. Once thus preoccupied, many never gained full sight of the law that other developers were up to or down to. Even within recent years, when new critics have sought to make up for this oversight, they have had the aspect of parvenus in the critical journals. These new reporters of long unguarded affairs are gaining space, ${ }^{6}$ but they are still far from parity with the orthodox critics who rally only to a run on the courthouse.

Yet there have been far-reaching changes in the panorama of the law, quite apart from its steady enlargement. Once upon a time, now long ago, the courthouses were in the foreground, legislatures were in the background, and an occasional administrative board sat on the outskirts, devoted to such lackadaisical activities as the receipt of stamp taxes and the disbursement of stamps. The judges worked at their carpentry on the common law, embellishing or disfiguring it according to their talent for construction or botch. The legislators usually hearkened if enough people or the right people said there ought to be a law, and periodically they tapped out a code. The administrators went about their stamp activities with such circumspection that no one ever felt impelled to declare that the time had come for another tea break of rock-and-roll proportions. It was conducive to this way of life in the law that so many people lived in the country.

Few foresaw how many would soon live in the city, and even now few have seized all the import of the change. A prescient observer might have foretold that courthouses would no longer dominate the legal panorama, that legislatures would advance from the background, and that administrative boards would divide and multiply until they were a sight to make sore eyes sorer. The high-rise laws of the legislatures presently towered over the landscape, though with the eventual effect of accentuating rather than effacing the uniqueness and durability of the carpentered cottages of the common law. ${ }^{7}$

It is of course a glaring trick on perception that the common law now appears relatively smaller than before. Actually common law too is growing apace, even if not so spectacularly. Among other things, judges are called upon to interpret all manner of statutes and

- See, e.g., Fordham, The State Legislative Institution 49 (1959).

7 Id. at 17 . 
to fit more and more pieces of statutory law into the continuity script of the common law. There are no reliable formulas for such a job; it is necessarily creative. In any event we do not measure the significance of law by dimension or bulk; nor should we imagine competition between two processes of lawmaking that are in fact correlative. If human aspiration is infinite, then so is the law, and so are the forms it can take.

I would not labor these observations were it not that they lead us to tangential light on our inquiry into the double standard of vigil. That double standard is fostered, perhaps inadvertently, by a dwindling but still highly vocal group who view with alarm any continuing development of the common law. In the mental graveyard of this set, the law is set forth in two kinds of tablets with no correlation between them. There are statutory tablets, of flexible material, cut to order in all sizes and shapes, from the skimpy to the outlandish. Legislators thus appear as normally creative, revising or liquidating their tablets as they see fit. In supposed antithesis are common-law stone tablets of mysterious origin that have always been where they are, complete with slots in which a judge deposits his question to receive in return the applicable rule of law, preferably no more than one. In this view, though judges resort to legerdeplume to create an illusion of kinship between burned-out coals of ancient sapience and the electric eels of unprecedented problems, they do not now nor did they ever create law. Before the judges the stone tablets were, presumably, concealed in the bushes.

It is mechanical in the extreme thus to deny the creative element in the judicial development of the law, merely because judges keep their dispassionate distance from the centers where new laws are innovated. Nevertheless, the stone-tablet cohorts still spread the gospel that judicial law alone is autonomous and moreover possessed of such pearly lore that it must be jealously guarded as is no other law. The vigil they keep on judicial law is one less of criticism than of upraised pitchforks against evolution. What they place on a pedestal, call it a woman or call it the law, they guard not from love of reason but from fatuous attachment to the familiar. Even when time has patently bereaved their idols of virtue, they would still oppose demolition except by the legislature. ${ }^{8}$ Even when their idols were devoid of virtue from the outset, they would preclude courts from undoing well what they have done badly. Though they do not seriously detract from the scrutinizing rounds of true courthouse critics, they unfortunately help to divert attention from all that goes on elsewhere. Among scholars

${ }^{8}$ See People v. Pierce, 395 P.2d 893, 895, 40 Cal. Rptr. 845, 847 (Sup. Ct. 1964). 
one tends to underestimate, if not to forget, how influential the diehards still are.

The relative weakness of the vigil that both true critics and uncritical vigilantes keep on other fronts may be in part attributable also to the popular image that lawmakers outside the courts are representatives of their public rather than of the law per se. The corollary is that whatever laws they make are in sincere response to public sentiment, and hence need not be tested for wisdom unless their very constitutionality is in issue. Does it follow that though they may howl with madness, we should let howling dogs by? If their rampages evoke criticism, should it be so diluted with tolerance as to be ineffective? If a mad bill is about to become law, should critics not at least sound the alarm? If a mad law is abroad in the land, should we not at least issue regular bulletins as to where it appears to be heading? Is there not more reason than ever to do so when it has no tether of tradition to keep it within reasonable bounds? Is it not a wild non sequitur that if a law has no tie with the past, its future is none of our business?

It becomes more than ever our business now that legislatures are the predominant lawmakers even in traditional areas of the common law. Whatever the variation in their personnel and resources, they are situated, as courts are not, to initiate comprehensive laws on massive problems and to revise them in the light of new data. It falls to them to take the lead in providing growth and diversification in the law to keep pace with the growth and diversification of public or private or mixed enterprise. Thus it is as normal for a code to carry a pocket supplement as it would be beyond bounds for a judicial decision to do so. The statute is the current installment of a neverending story. The decision is by definition decisive, the closing chapter of a controversy. For better or worse it plays its bit part in the common law in its first and only edition.

In sum the legislators are the plant managers of the law, free to roam and see for themselves what the public needs, and free to produce accordingly in plants sometimes well-equipped with research and development staffs and well-geared for production. Their twofold freedom would seem conducive to the most rational lawmaking. In contrast judges are confined to working indoors exclusively and confined to the problems of those who have sought them out with proper credentials. Indoors they stay, preoccupied with the record, riddled though the record may be with the complications and confusion of long and often bitter quarrel. Their twofold constriction would not seem favorable for the most rational lawmaking. 
Nevertheless, the traditions of judicial office that operate against external pressures serve to render the judicial process signally rational in spite of its constrictions. Conversely, the vulnerability of legislative office to external pressures and the stubborn survival of caliph committee structures in too many areas work against the seemingly rational processes of lawmaking available to legislators. ${ }^{9}$ Hence constant vigil becomes imperative.

Given a close watch on the scene of legislation, legislative offices could develop traditions of independence and even of active cooperation with legal centers of known objective scholarship. After all, the traditions of independence in judicial office, nurtured today in an environment of scholarship and tending to take hold of even popularly elected judges, followed a heyday of untidy backfireside justice in the so-called Jacksonian era of the judiciary, when scholarship and independence suffered concurrent depreciation. It is not surprising that both now thrive because of stern vigil. ${ }^{10}$ A comparable vigil on the legislative process could in time give the lie to the cynical aphorism that it is easier to legislate than to litigate.

There are many good men in our legislatures, and many lawyers among them, who would welcome such a vigil. Of course the legislative process would continue to involve constant adjustment of conflicting interests, but there is every reason to arrive at such adjustments in the light of objective studies and objective criticism.

An effective watch upon the legislative process requires more than the vigilant law journals that scrutinize the documented and readily available accounts rendered of the judicial process. We have not yet mustered all the resources even of such journals, however, in the needed vigil, though more and more they are taking the initiative to serve as constructive critics of legislative law. ${ }^{11}$ They can do much to counteract the fitful ways of the legislative process. Its feats of clumsiness have been vividly set forth by Judge Friendly, who laments that "the legislator has diminished the role of the judge by occupying vast fields and then has failed to keep them ploughed." 12 Certainly courts

9 See, e.g., Griffith, Congress-Its Contemporary Role (3d ed. 1961); Gross, The Legislative Struggle (1953); Wilson, Congressional Government (1885). (1962),

10 See Traynor, To the Right Honorable Law Reviews, 10 U.C.L.A.L. REv. 3

11 See, e.g., Traynor, Comment, in Legal Institutions Today and Tomorrow 48, 66 (1959); Packer \& Gampell, Therapeutic Abortion: A Problem in Law and Medicine, 11 Stan. L. Rev. 417 (1959); Legislation, 17 VAND. L. REv. 325, 638, 1354 (1963-1964); Legislation, 16 VAND. L. REv. 1261 (1963); Project, Legislative Regulation of Retail Installment Financing, 7 U.C.L.A.L. REv. 618 (1960); Survey of 1949 Ohio Legislation, 10 Онго Sт. L.J. 413 (1949).

12 Friendly, The Gap in Lawmaking-Judges Who Can't and Legislators Who Won't, 63 Colum. L. Rev. 787, 792 (1963). 
are helpless to stay the maddening sequences of triumphal entry and sit-in. ${ }^{13}$ What is frustration to them, however, can be challenge to the scholars. Steeped in special knowledge of one field or another, they can well place their knowledge at the service of legislatures for the plowing of the fields, for their sowing and their care. "Who but the scholars have the freedom as well as the nurturing intellectual environment to differentiate the good growth from the rubbish and to mark for rejection the diseased anachronism, the toadstool formula, the scrub of pompous phrases?" 14

There is a tragic waste in the failure to correlate all our machinery for vigil to maximum advantage. Is it not time to break the force of habits that militate against steady communication between legislators in unplowed fields and scholarly watchbirds in bleachers? It is for no more sinister reason than lethargy that we have failed in large measure to correlate the natural resources of legislators who have an ear to the ground for the preemption of new fields and of scholars who have an eye on their long-range development. Perhaps we can make a beginning by calling upon legislators to take the initiative in establishing permanent lines of communication. The scholars can hardly take that initiative, for they are not lobbyists. ${ }^{15}$ Why not invite their ideas through the good offices of a legislative committee that can insure their careful consideration? Why not, particularly when some legislatures are now equipped with permanent legislative aids, ${ }^{16}$ and

13 See Riesenfeld, California Legislation Curbing Deficiency Judgments, 48 CALIF. L. Rev. 705, 728 (1960); Traynor, No Magic Words Could Do It Justice, 49 CAlif. L. Rev. 615, 628 (1961)'. See also Salsbery v. Ritter, 48 Cal. 2d 1, 9-14, 306 P.2d 897, 901-04 (1957).

14 Traynor, Law and Social Change in a Democratic Society, 1956 U. ILL. L.F. $220,233$.

15 Professor Dunham, in commenting on the law revision group projects at the University of Chicago Law School, notes that such participation need not involve advocacy, for "we can successfully immunize ourselves from a role which we should not assume-that of promoting the passage of any legislation drafted." The Law School Record, University of Chicago, Fall 1955, pp. 4-5.

16 In summary form the major aids are:

Law Revision Commissions: Only California (1953) and New York (1934) have such a commission.

Legislative Counsel Bureaus: California (1913), Georgia (1959), Nevada (1945), and Oregon (1953) have a "legislative counsel" by that title. Twenty-four additional states have a variety of officers or agencies that appear to perform some of the functions of the California Legislative Counsel.

Legislative Councils: Forty-two states have official bodies entitled "legislative council," or an equivalent title. In a number of instances these councils or their staffs perform some of the legislative service functions of a legislative counsel.

Judicial Councils: Thirty-three states have a judicial council. In an additional nine states there is a judicial conference that performs a similar function. In several of these latter states, the judicial conference succeeded a prior judicial council.

Bureaus of Public Affairs: There are fifty-four universities located in thirty-nine states that have institutes of governmental studies or bureaus of public affairs. 
here and there law schools have now set up legal centers, and there remains only to set up permanent lines of communication between them?

The following table sets forth such aids in each state and the dates of their establishment:

Alabama

Alaska

Arizona

Arkansas

California

1953

1913

$\begin{array}{cc}\begin{array}{l}\text { Legis- } \\ \text { lative } \\ \begin{array}{c}\text { Council } \\ 1945\end{array}\end{array} & \begin{array}{l}\text { Judicial } \\ \text { Council }\end{array} \\ & \\ 1953 & 1959 \\ 1953 & \\ 1947 & 1941 \\ & 1926\end{array}$

Committee on

Statute Revision (1951)

Connecticut

Delaware

Florida

\section{Georgia}

Hawaii

Idaho

Illinois
Legislative

Research

Department (1947)

Legislative

Reference

Bureau (1945)

1949

Office of

Legislative

Counsel (1959)

Statutes (1959)

Legislative

Reference

Bureau (1913)

1937
Revisor of
1953

Bureau
of Public
Affairs

University of Alabama (1939)

Arizona State University (1959)

University of Arkansas (1957)

University of California, Berkeley (1920); Davis (1935) ; L.A. (1937)

San Diego State College (1957)

1958 University of Colorado (1960)

1927

University of Connecticut (1944)

1955

1953

University of

Florida (1947);

Florida State University (1947)

$1959 \quad 1945$

1955

1963 Judicial Con- University of Idaho ference (1951) (1959)

1937 Judicial Con- University of Chiference (1957) cago (1954) ; University of Illinois (1947) ; Northwestern University (1953) ; Southern Illinois University (1951) 
The natural agency for such communication is a law revision commission such as now exists in New York and California. A state that muddles along without one needlessly muddles along on donkeypower when horsepower is readily available.

\begin{tabular}{|c|c|c|c|c|c|}
\hline & $\begin{array}{l}\text { Law } \\
\text { Revision } \\
\text { Com- } \\
\text { mission a }\end{array}$ & $\begin{array}{c}\text { Legislative } \\
\text { Counsel } \\
\text { Bureau a }\end{array}$ & $\begin{array}{l}\text { Legis- } \\
\text { lative } \\
\text { Council }\end{array}$ & $\begin{array}{l}\text { Judicial } \\
\text { Council }\end{array}$ & $\begin{array}{l}\text { Bureau } \\
\text { of Public } \\
\text { Affairs }\end{array}$ \\
\hline Indiana & & $\begin{array}{l}\text { Legislative } \\
\text { Bureau (1907) }\end{array}$ & 1945 & $\begin{array}{c}1935-1953 \\
1960\end{array}$ & $\begin{array}{l}\text { Indiana University } \\
\text { (1937) }\end{array}$ \\
\hline Iowa & & & 1955 & $\begin{array}{l}\text { 1959; Judicial } \\
\text { Conference } \\
\text { (1959) }\end{array}$ & $\begin{array}{l}\text { State University of } \\
\text { Iowa (1949) }\end{array}$ \\
\hline Kansas & & $\begin{array}{l}\text { Revisor of } \\
\text { Statutes (1929) }\end{array}$ & 1933 & 1927 & $\begin{array}{l}\text { University of Kan- } \\
\text { sas (1909); Uni- } \\
\text { versity of Wichita } \\
(1958)\end{array}$ \\
\hline Kentucky & & & 1936 & 1928 & $\begin{array}{l}\text { University of Ken- } \\
\text { tucky (1937) }\end{array}$ \\
\hline Louisiana & & $\begin{array}{l}\text { State Law } \\
\text { Institute } \\
\text { (1938) }\end{array}$ & 1952 & 1950 & $\begin{array}{l}\text { Louisiana State } \\
\text { University (1936) }\end{array}$ \\
\hline Maine & & & 1939 & 1932 & $\begin{array}{l}\text { Bowdoin College } \\
\text { (1914) }\end{array}$ \\
\hline Maryland & & $\begin{array}{l}\text { Department of } \\
\text { Legislative } \\
\text { Reference } \\
(1916)\end{array}$ & 1939 & $\begin{array}{l}\text { Judicial Con- } \\
\text { ference (1945) }\end{array}$ & $\begin{array}{l}\text { University of } \\
\text { Maryland (1947) }\end{array}$ \\
\hline Massachusetts & & & 1954 & 1924 & $\begin{array}{l}\text { Boston University } \\
\text { (1947) ; Harvard } \\
\text { University (1911); } \\
\text { University of Mas- } \\
\text { sachusetts (1956) }\end{array}$ \\
\hline Michigan & & $\begin{array}{l}\text { Legislative } \\
\text { Service Bu- } \\
\text { reau (1941) }\end{array}$ & 1964 & $\begin{array}{l}\text { 1929-1955; } \\
\text { Judicial Con- } \\
\text { ference (1954) }\end{array}$ & $\begin{array}{l}\text { Michigan State } \\
\text { University (1957); } \\
\text { University of } \\
\text { Michigan (1914) }\end{array}$ \\
\hline Minnesota & & $\begin{array}{l}\text { Revisor of } \\
\text { Statutes (1939) }\end{array}$ & 1947 & 1937 & $\begin{array}{l}\text { University of Min- } \\
\text { nesota (1913) }\end{array}$ \\
\hline Mississippi & & $\begin{array}{l}\text { Revisor of } \\
\text { Statutes (1944) }\end{array}$ & & & $\begin{array}{l}\text { University of Mis- } \\
\text { sissippi (1945) }\end{array}$ \\
\hline Missouri & & & 1943 & $\begin{array}{l}\text { Judicial Con- } \\
\text { ference (1943) }\end{array}$ & $\begin{array}{l}\text { University of Mis- } \\
\text { souri }(1957) ; \text { Park } \\
\text { College (1955) }\end{array}$ \\
\hline Montana & & & 1957 & & $\begin{array}{l}\text { Montana State } \\
\text { University (1956) }\end{array}$ \\
\hline Nebraska & & $\begin{array}{l}\text { Revisor of } \\
\text { Statutes (1945) }\end{array}$ & 1937 & 1939 & \\
\hline Nevada & & 1945 & 1945 & & $\begin{array}{l}\text { University of } \mathrm{Ne} \text { - } \\
\text { vada }(1959)\end{array}$ \\
\hline
\end{tabular}


One could begin in every state with an inventory of needed or neglected aids that could be utilized both to improve and to expedite legislative lawmaking. One could appraise to what extent they have done so. Thus a 1951 tabulation in my state begins by defining the

\begin{tabular}{|c|c|c|c|c|c|}
\hline & $\begin{array}{l}\text { Law } \\
\text { Revision } \\
\text { Com- } \\
\text { mission a }\end{array}$ & $\begin{array}{c}\text { Legislative } \\
\text { Counsel } \\
\text { Bureau a }\end{array}$ & $\begin{array}{l}\text { Legis- } \\
\text { lative } \\
\text { Council }\end{array}$ & $\begin{array}{l}\text { Judicial } \\
\text { Council }^{\text {e }}\end{array}$ & $\begin{array}{c}\text { Bureau } \\
\text { of Public } \\
\text { Affairs }\end{array}$ \\
\hline New Hampshire & & $\begin{array}{l}\text { Office of } \\
\text { Legislative } \\
\text { Service (1963) }\end{array}$ & 1951 & 1945 & $\begin{array}{l}\text { University of New } \\
\text { Hampshire (1953) }\end{array}$ \\
\hline New Jersey & & $\begin{array}{l}\text { Law Revision } \\
\text { and Legislative } \\
\text { Services Com- } \\
\text { mission (1954) }\end{array}$ & 1954 & $\begin{array}{l}\text { 1930-1950; } \\
\text { Judicial Con- } \\
\text { ference (1948) }\end{array}$ & $\begin{array}{l}\text { Princeton Univer- } \\
\text { sity (1935); Rut- } \\
\text { gers University } \\
(1950)\end{array}$ \\
\hline New Mexico & & & 1951 & 1954 & $\begin{array}{l}\text { University of New } \\
\text { Mexico (1945) }\end{array}$ \\
\hline New York & 1934 & & & $\begin{array}{l}\text { 1934-1955; } \\
\text { Judicial Con- } \\
\text { ference (1955) }\end{array}$ & \\
\hline North Carolina & & & 1963 & 1949 & $\begin{array}{l}\text { University of } \\
\text { North Carolina } \\
(1920)\end{array}$ \\
\hline North Dakota & & & 1945 & 1927 & \\
\hline Ohio & & & 1943 & 1923 & \\
\hline Oklahoma & & & 1939 & 1943 & $\begin{array}{l}\text { University of Okla- } \\
\text { homa }(1920)\end{array}$ \\
\hline Oregon & & $\begin{array}{l}\text { Legislative } \\
\text { Counsel Com- } \\
\text { mittee (1953) }\end{array}$ & & 1955 & $\begin{array}{l}\text { University of Ore- } \\
\text { gon (1933) }\end{array}$ \\
\hline Pennsylvania & & $\begin{array}{l}\text { Legislative } \\
\text { Reference } \\
\text { Bureau (1909) }\end{array}$ & 1937 & $\begin{array}{l}\text { Judicial Con- } \\
\text { ference (1928) }\end{array}$ & $\begin{array}{l}\text { Pennsylvania State } \\
\text { University (1959); } \\
\text { University of Penn- } \\
\text { sylvania (1937); } \\
\text { University of } \\
\text { Pittsburgh (1944) }\end{array}$ \\
\hline Rhode Island & & & 1939 & $\begin{array}{c}1927-1935 \\
1939\end{array}$ & \\
\hline South Carolina & & $\begin{array}{l}\text { Code Commis- } \\
\text { sioner (1954) }\end{array}$ & 1949 & 1956 & $\begin{array}{l}\text { University of } \\
\text { South Carolina } \\
(1945)\end{array}$ \\
\hline South Dakota & & $\begin{array}{l}\text { Revisor of } \\
\text { Statutes (1951) }\end{array}$ & 1951 & 1933 & $\begin{array}{l}\text { State University of } \\
\text { South Dakota } \\
\text { (1939) }\end{array}$ \\
\hline Tennessee & & $\begin{array}{l}\text { Code Commis- } \\
\text { sion (1953) }\end{array}$ & 1953 & 1943 & $\begin{array}{l}\text { University of Ten- } \\
\text { nesse (1945) }\end{array}$ \\
\hline Texas & & & 1949 & 1929 & $\begin{array}{l}\text { University of } \\
\text { Texas (1913) }\end{array}$ \\
\hline
\end{tabular}


It was not until 1953 that the California Law Revision Commission was established, with headquarters at Stanford University, following the example of the New York Law Revision Commission, established in 1934, with headquarters at Cornell University. Its 1964 report lists fifty-seven bills and two proposed constitutional amendments that it drafted and presented to the legislature. Thirty-nine of the bills were enacted, as well as one constitutional amendment. Since 1953 it has engendered massive statutory revision in such fields as arbitration and claim procedures in actions against public entities. ${ }^{20}$

Many problems stand in need of just such massive solution. Though they cry for attention, they may nevertheless be neglected indefinitely, often enough because they originated as common-law problems and were purportedly laid at rest by judicial decision. If a court at last abandons an unsound or outworn rule, forthrightly setting forth the painstaking analysis that such a renunciation demands, ${ }^{21}$ it may trigger the massive action on the legislative front necessary to resolve the problem in comprehensive fashion. Thus, when the California Supreme Court renounced the doctrine of sovereign immunity in $1961,{ }^{22}$ it triggered a comprehensive study of the doctrine by the law revision commission. That study became the basis of statutory law ${ }^{23}$ governing various ramifications of a problem that had cast many shadows beforehand and that could hardly be resolved in so large a context within the confines of judicial decision, except by costly litigation over a long span of time.

The California Law Revision Commission has also proposed a code of evidence for the consideration of the Conference of California Judges and of the state bar before presentation to the legislature. ${ }^{24}$ In

20 See 4 Cal. Law Revision Comm. Reports, Recommendations, and Studies 208 nn.6-11 (1963). The arbitration statute, Cal. Stats. 1961, ch. 461, was based upon 3 Cal. Law Revision Comm. Reports, Recommendations, and Studies G-1 to -64 (1961). The revision of the claims procedures, Cal. Stats. 1959, chs. 1724-28 (repealed by 2 Cal. Stats. 1963, ch. $1715, \S 6$, at 3395 ), was based upon 2 CAL. Law Revision Comm. Reports, Recommendations, and Studies A-1 to -128 (1959).

21 See Morris, Liability for Pain and Suffering, 59 CoLUM. L. REv, 476, 483-85 (1959); Traynor, La Rude Vita, La Dolce Giustizia; or Hard Cases Can Make Good Law, 29 U.' CHI. L. Rev. 223, 232 (1962).

${ }^{22}$ Muskopf v. Corning Hospital Dist., 55 Cal. 2d 211, 359 P.2d 457, 11 Cal. Rptr. 89 (1961); see Lipman v. Brisbane Elementary School Dist., 55 Cal. 2d 224, 359 P.2d 465, 11 Cal. Rptr. 97 (1961) ; 3 Davis, Administrative Law Treatise \$25.01 (Supp. 1963); Traynor, La Rude Vita, La Dolce Giustizia; or Hard Cases Can Make Good Law, 29 U. CHI. L. Rev. 223, 230-31 (1962); Van Alstyne, Governmental Tort Liability: Judicial Lawmaking in a Statutory Milieu, 15 Stan. L. Rev. 163 (1963); Van Alstyne, Governmental Tort Liability: A Public Policy Prospectus, 10 U.C.L.A.L. REV. 463 (1963).

23 The revision of the statutes governing sovereign immunity, 2 Cal. Stats. 1963, chs. 1681-86, 1715, 2029, was based upon 4 CAL. LAW Revision Comm. Reports, Recommendations, and Studies 801-1611 (1963) and 5 Cal. Law Revision Comm. Reports, Recommendations, and Studies 565 (1963).

24 See 4 Cal. Law Revision Comm. Reports, Recommendations, and Studies 301-619 (1963); Cal. Law Revision Comm. Tentative Recommendation and A Study Relating to the Uniform Rules of Evidence (1964). 
1965 the legislature, with the benefit of both scholarly research and the comment of judges and lawyers, will be in a fair way to modernize the law of evidence.

In our affluent country there is every reason to establish a law revision commission in each of the forty-eight states that is without one. A legal center situated within the purview of a law school could afford an ideal environment for such a commission. It could there devote itself wholeheartedly to the formulation and drafting of statutes as well as to continuing re-examination of their fitness for survival. It could withstand the prevailing winds of pressure groups as it made timely use of the abundant wasting assets of scholarly studies. One can hardly imagine interchange more valuable for the law than that between those entrusted to review it critically and those entrusted to draft proposals for its revision. On a wide front they could collaborate in long-range studies of legal needs that would richly complement the applied research that legislatures recurringly ask of their legislative aids. In turn the work of the commissions would offer hearty sustenance not only to the law reviews but to all the other projects of a law school, not the least of which is the classroom. Such permanent relationships between law schools and law revision commissions, going far beyond today's ad hoc partnerships, would strengthen their beneficent influence on legislation.

In fostering communication between legislators and law schools, a law revision commission is bound to become alert to local aspects of those problems that lend themselves to resolution by uniform laws such as are proposed by the National Conference of Commissioners on Uniform State Laws. It can undertake the double responsibility of expediting enactment of a uniform law when it is well adapted to the local scene or of suggesting local adaptations when they seem necessary. A proposed uniform law is usually designed to raise local standards, but a law revision commission can nonetheless be on the alert for any provision that would lower them. There should be no slackening of the vigil on the jealous mistress when she turns up in a uniform. What still counts is her intrinsic virtue and how well she is put together.

A law revision commission could likewise scrutinize the restatements of the American Law Institute, as well as its proposed model acts, for possible local adoption or adaptation. It could study to good purpose the proposals of the Institute of Legal Research of the University of Pennsylvania Law School and the Institute of Judicial Administration at New York University. Certainly it should also keep informed, if only to avoid wasteful duplication, of the growing output 
of the American Bar Foundation and the American Judicature Society. Above all it should watch all proposals in law journals for legislative action. A quick check revealed that the law reviews in my own state published a total of well over two hundred such proposals since 1950 . A similar check in Pennsylvania revealed almost one hundred proposals for law reform in a single law review in the past eight years, and a statewide total approximately equal to that in California since 1950. It is a fair guess that few of them have made their way to the desks of the legislators for even cursory appraisal.

A law revision commission has within easy reach this wealth of usable material. Indeed, the growing embarrassment of all these riches is that they often fail to produce steady interest, let alone a capital gain. There is no sorrier sight than a slatternly mistress shambling in unkempt raiment amid endless bolts of rich material that are hers for the asking and kicking aside even tailored garments that she could freely alter to meet her measurements. No one expects her to look as beatific in action as in a clay image, but without great effort she could look reasonably neat and smart.

Now and again it may be appropriate to supplement the work of law revision commissions with projects entrusted to a special task force. Thus the California Joint Legislative Committee for Revision of the Penal Code has entrusted to a group of law professors assisted by an advisory board of judges and lawyers a three-year study directed toward a substantive code, a code of criminal procedure, and a corrections code. ${ }^{25}$

The growing disposition of legislators to make use of such objective studies in my state improves the coherence and continuity of statutory law. Since legislation, or the lack of it, now mainly determines the course of judicial administration and procedure, a judge is impelled to take special interest in any aids that can improve statutory law in this area. It is a neglected area in which the jealous mistress has cast one of her dizziest spells. Scholars have now and again described the blight in rousing terms, ${ }^{26}$ but in the main to no great avail.

252 Cal. Stats. 1963, ch. 1797.

${ }^{26} \mathrm{~A}$ notable example is the work of the Columbia University Project for Effective Justice, organized in 1956, in the field of judicial procedure. Among their major studies are: Rosenberg, Critique of Methods Used To Expedite Litigation, in 11 N.J. Judicial Conference 1 (1959); Franklin, Chanin \& Mark, Accidents, Money, and the Law: A Study of the Economics of Personal Injury Litigation, 61 CoLUM. L. REv. 1 (1961) ; Rosenberg \& Chanin, Auditors in Massachusetts as Antidotes for Delayed Civil Courts, 110 U. PA. L. REv. 27 (1961); Rosenberg \& Schubin, Trial by Lawyer: Compulsory Arbitration of Small Claims in Pennsylvania, 74 HARv. L. REv. 448 (1961); Rosenberg \& Sovern, Delay and the Dynamics of Personal Injury Litigation, 59 ColuM. L. REv. 1115 (1959); Rosenberg, Sanctions To Effectuate Pretrial Discovery, 58 Colum. L. Rev. 480 (1958). See also Holbrook, A Survey of Metropolitan Trial Courts, Los Angeles Area (1956); Levin \& Woolley, Dispatch and Delay: A Field Study of Judicial Administration in Pennsylvania (1961); 
Perhaps blight persists in this area because of its undramatic nature. One is not likely to come upon villains who despoil it, such as could stir crusaders to action. It encompasses no extraordinary resources, such as could stir the imaginative to exploration. It offers no sensational material for headlines. One can hardly imagine the average household reaching a pitch of righteous indignation over some crazed law on practice or procedure that in its quiet way does no more than obstruct justice daily.

Though the American Judicature Society reports notable reforms within the last decade and strong support for more, ${ }^{27}$ what remains to be done still looms larger by far than what has been done. In my own state the filaments of all too many cobwebbed statutes still enmesh court procedures, even those of modern aspect. ${ }^{28}$ In Professor Geoffrey Hazard's apt summary of the madness in California: "Those who would deal with California procedure, therefore, must be not merely historians but archeologists, alert to detect in the foundations of a modern case or statute the shards of an older procedural culture." ${ }^{29}$ One might add that only fond lawyers would be tolerant of a mistress so indiscriminately all things to all men.

Schulman, Toward Judicial Reform in Pennsylvania (1962); Zeisel, Kalven \& Buch holz, Delay in the Court (1959); Kalven, The Bar, the Court, and the Delay, 328 Annals 37 (1960); Kalven, The Jury, the Laze, and the Personal Injury Damage Award, 19 Онго Sт. L.J. 158 (1958).

27 See Winters, The National Movement To Improve the Administration of Justice, 48 J. Aм. Jud. Soc'y 17, 19-21 (1964).

28 For example, there are fifty-six sections of the California Code of Civil Procedure, CAL. CIV. PRO. Code $\$ \S 420-75$, relating to pleadings, as against nine rules in the Federal Rules of Civil Procedure, FED. R. CIV. P. 7-15. They constitute a petrified forest dating back to 1872 .

Federal Judge Charles E. Clark, in reviewing Chadbourne, Grossman \& Van Alstyne, California Pleading (1961), commented: "As yet [California's] . . only essay into the most modern reform of the federal rules appears to be the adoption of some of the party joinder rules in 1927, the rule for summary judgments as amended in 1953, and the discovery rules in 1958." Clark, Book Review, 8 U.C. L.A.L. REv. 994 (1961). In contrast there has been notable progress in some of the other states.

29 Hazard, Book Review, 8 U.C.L.A.L. Rev. 1012, 1013 (1961) (reviewing Chadbourne, Grossman \& Van Alstyne, California Pleading (1961)). In Professor Hazard's vivid context:

California procedure is difficult, finally, because in no jurisdiction's procedural structure, except perhaps that of New York, is there such an incongruous coexistence of the ancient and the modern in procedural rule and policy. In some states, such as Oregon, the old Field Code lives on in undisturbed slumber. In others, such as Washington, Arizona and New Mexico, the Federal Rules of Civil Procedure have been adopted root and branch and most of the old learning cast out. But in California, we have at one and the same time the old special demurrer and the new modern interrogatory to a party, both usable for the purpose of eliciting a detailed statement of position from the opposing party. We have at one and the same time maximum latitude for joinder of parties plaintiff and niggling and annoying limitations on counter-claims. There are dozens of other illustrations.

Ibid. 
The extraordinary mélange of sense and nonsense in my own state affords enough of an object lesson to prompt a brief inquiry into how the hodgepodge originated, why the nonsense came to survive, and what the prospects are of bringing it to a hightimely end. Consider for a moment a history that is not likely to repeat itself. Envisage a mountainous country overlooking the Pacific Ocean where Spanish-speaking missionaries were establishing communication with Indians on the cultivation of the land at a time when their contemporaries in Philadelphia were working furiously on their Anglo-Saxon law books. This far country became a state in 1850 amid a gold rush hardly conducive to scholarly deliberation on judicial procedure. An immediate task of the pioneer society was to create a judicial system overnight against a background of Spanish and Mexican law. There was restlessness in the pioneers over the formalism in the common law. So it came about that the twig was bent toward codification in the Field Codes of 1872, though these were fertile with common law. Minute details of judicial procedure were embedded into statutes, and additions and amendments in bits and pieces rendered these statutes in time as strange in design as a coral reef and stranger still in their juxtaposition of skeletal and living substance.

Into this submarine life California in 1879 launched one of the heaviest constitutions ever to stay afloat. For all its ponderosity it starts off buoyantly, setting forth as inalienable the right not merely to pursue but to obtain safety and happiness. ${ }^{30}$ Apparently the pioneer framers themselves felt neither secure nor happy about lawmakers, for they conceived a mass of restrictions on both the legislature and the courts.

No one constrained by such fetters lives with them happily ever after. A change for the better came for the courts in 1926 when a constitutional amendment provided for a judicial council under the chairmanship of the chief justice. ${ }^{31}$

The judicial council's responsibility is akin to that of a law revision commission in the limited field of practice and procedure. The California constitution directs it to "adopt or amend rules of practice and procedure for the several courts . . . ." 32 The hitch is that they must be consistent "with laws that are now or that may hereafter be in force... . " 33 That is a hitch of some consequence in view of the myriad laws in force. Though the council has adopted many

${ }^{30}$ CAL. Const. art. I, $\S 1$.

31 CaL. Const. art. VI, §1a.

32 Ibid.

${ }^{33}$ Ibid. 
rules that merely supplement statutes, the prospects of establishing a new rule are often likely to depend upon the liquidation of an entrenched statute. Still, a statute no longer has quite the formidable advantage of an incumbent, for the constitution directs the judicial council to "submit to the Legislature, at each regular session thereof, its recommendations with reference to amendments of, or changes in, existing laws relating to practice and procedure." 34

Thus the judicial council is well situated to give the impetus to change, and it has done so in limited areas, although it has not undertaken any wholesale renovation. In 1943, pursuant to a delegation of power from the legislature, it promulgated comprehensive rules governing appellate practice and procedure,$^{35}$ which replaced conflicting statutes that were accordingly repealed. Hence California now has modern appellate procedures that are regularly kept up-to-date under the council's broad power to make adjustments when the need arises. The advantage of flexible adjustment over statutory fetters is strikingly illustrated by the contrast between the well-kept appellate procedures in California and the unkempt trial procedures that have yet to be released from the mess of statutes that control them.

Such unkemptness looms particularly large in view of the rehabilitation in the procedures of administrative boards effectuated by the judicial council, acting upon authority of the legislature. Its studies led to the Administrative Procedure Act ${ }^{36}$ which established uniform rules of practice and procedure of statewide statutory agencies in issuing, suspending, and revoking professional and business licenses and similar rights or privileges. Upon the council's recommendation the legislature provided for a division of administrative procedures entrusted with the continuing study of all aspects of administrative law and procedure.

The judicial council also acted upon a grant of authority from the legislature to draft a reorganization plan for the lower courts. It culminated in a constitutional amendment in $1950^{37}$ that opened the way to reducing the number of lower courts from 768 to less than $400^{38}$ and replaced eight types of courts, some with overlapping jurisdiction,

34 Ibid.

35 See Witkin, New California Rules on Appeal (pts. 1-2), 17 So. Cal. L. Rev. 79, 232 (1944). See also Cal. Judicial Council Tenth Biennial Rep. pt. 1, at 6 (1944).

36 Cal. Gov't Code $\$ \S 11500-28$; see Cal. Judicial Council Eleventh Biennial Rep. pt. 1, at 11 (1946); Cal. Judicial Council Tenth Biennial Rep. pt. 2, at 8 (1944); Kleps, Report on the Reform of Administrative Procedure, 20 CAL. S.B.J. 124 (1945).

37 Cal. Const. art. VI, $\S 1,11$. See generally Cal. Judicial Council Twelfth Biennial ReP. pt. 1 , at 13 (1948).

38 See Cal. Judicial Council Fourteenth Biennial Rep. pt. 1, at 16 (1953). 
by two, municipal courts and justice courts. As part of this reform, lay candidates for judge of the justice court are required to pass a qualifying examination given by the judicial council. ${ }^{39}$

One of the most interesting achievements of the judicial council was the groundwork it laid for a constitutional amendment in $1960^{40}$ establishing a commission on judicial qualifications. This commission affords a means not only for retiring judges with incapacitating disabilities, but also for removing judges for misconduct in office. The unregenerate who occasionally turns up in any walk of life presents a problem that requires careful handling, for a bad man is as hard to lose as a good man is hard to find. The policing of its own ranks by the judiciary is already proving an effective way of resolving the problem. ${ }^{41}$

Until recently we had yet to deal with another problem of no less delicacy, though it involved only words and not deeds. "If we are in earnest about the rational growth of the law, we are bound to be concerned with the form and content of opinions. Do we submerge ourselves and the profession in wild seas of paper only to exhaust ourselves in swimming out therefrom to be resubmerged?" 42 In $1963^{43}$ the California Legislature, acting upon a recommendation of the judicial council, took a step toward flood control by repealing a long-standing statutory requirement that all appellate court opinions be published. Though all must still be given in writing, ${ }^{44}$ the California Supreme Court this year adopted a rule limiting the publication of opinions by district courts of appeal to those deemed of value as precedents by whatever court issues them. ${ }^{45}$ There has been a drop in publication of over forty percent, and as yet no lawyers have been heard to complain that they feel deprived in their reading.

In 1955 the legislature delegated power to the judicial council to work out rules of pretrial procedure. ${ }^{46}$ The task involves the resolution of questions as controversial as they are complex, and the council has been painstakingly evolving and adjusting rules on the basis of experience. Enough experience has accumulated for a consolidation of gains toward a beneficent evolution of pretrial procedure. Whatever

39 CAL. Gov't CODE $\S 71601$.

${ }^{40} \mathrm{CAL}$. Const. art. VI, $\S \S 1 \mathrm{~b}, 10 \mathrm{~b}$.

41 See Frankel, Removal of Judges: California Tackles an Old Problem, 49 A.B.A.J. 166 (1963).

42 Traynor, Some Open Questions on the Work of State Appellate Courts, 24

U. Chi. L. Rev. 211, 212 (1957).

43 CAL. Gov't CODE $\S 68895$.

44 Cal. Const. art. VI, §§ 2, 24.

45 CAl. Sup. Ct. R. 976.

46 CAL. Gov't Code $\S 575$ (Supp. 1964). 
emotional resistance survives of those who are set in old ways and unduly suspicious of change should be dissipated in good season by such an evolution.

In other recent delegations of authority to the judicial council, the legislature has left it free to formulate and revise rules under which district courts of appeal review decisions of the appellate departments of the superior court, ${ }^{47}$ and superior courts review certain decisions of the municipal courts and justice courts. ${ }^{48}$

The California experience is of interest in the debate among experts as to whether the power to make rules of practice and procedure should rest exclusively with the courts. Dean Wigmore advanced one view in an article summarized in the simple declarative sentence of its title: "All Legislative Rules for Judiciary Procedure Are Void Constitutionally." ${ }^{49}$ Dean Pound supported this view in his report on "Procedure Under Rules of Court in New Jersey." so Chief Justice Vanderbilt of New Jersey also supported this view, ${ }^{\mathbf{5 1}}$ and it has been adopted in his state. ${ }^{52}$

The contrary view is persuasively stated by Professors Levin and Amsterdam of the University of Pennsylvania Law School. Rejecting an either-or solution of judicial rulemaking that would compel a choice between legislatures and courts, they state:

There is a middle scheme that holds out all of the advantages of judicial autonomy while severely minimizing its collateral 1964).

47 Cal. Crv. Proc. Code $\S 988 t$ (Supp. 1964); Cal. Pen. Code $\S 1471$ (Supp.

48 Cal. Civ. Proc. Code $\S \S 117 j, 988$ j (Supp. 1964).

4923 Ill. L. Rev. 276 (1928).

5066 Harv. L. Rev. 28 (1952). See also Address by Dean Pound, California Bar Association Seventh Annual Convention, Aug. 18, 1916, in Proceedings Seventh Annual Convention, California Bar Association 86, 112 (1916); id. at 163.

61 Vanderbilt, Minimum Standards of Judicial Administration 111 (1949); see Levin \& Amsterdam, Legislative Control Over Judicial Rule-Making: A Problem in Constitutional Revision, 107 U. PA. L. Rev. 1, 24-26 (1958).

52 N.J. Const. art. VI, §2, para. 3; Winberry v. Salisbury, 5 N.J. 240, 74 A.2d 406, cert. denied, 340 U.S. 877 (1950); see Kaplan and Greene, The Legislature's Relation to Judicial Rule-Making: An Appraisal of Winberry v. Salisbury, 65 HARv. L. REv. 234 (1951). The Michigan Supreme Court and the Florida Supreme Court apparently also have power to make rules of practice and procedure that are not subject to legislative veto or control. Mich. Const. art. VII, § 5; FLA. Const. art V, §3; Joiner \& Miller, Rules of Practice and Procedure: A Study of Judicial Rule Making, 55 Mich. L. REv. 623 (1957). The Michigan Supreme Court recently adopted a completely new set of court rules that are designated as the General Court Rules of 1963. See Honigman, Procedural Changes in Michigan, 31 F.R.D. 113 (1962). In Florida, when the judicial council came into existence in 1953, it listed as one of its major goals the vesting of full rule making power in the supreme court. This objective was realized by a 1956 constitutional amendment. FLA. Const. art. V, $\S 3$. Thereafter, the legislature formally subordinated existing conflicting statutory rules to the court-made rules. An interesting postscript is that a bill was introduced to abolish the judicial council. The bill was defeated and the council was permitted to survive but was denied any appropriation. Institute of Judicial Administration, Rule Making Power of the Courts, 1962, p. 4. 
dangers. This is the scheme of concurrent jurisdiction: granting to the courts full authority of initiative selfregulation, reserving to the legislature an ultimate voice to curb abuse. ${ }^{53}$

Levin and Amsterdam have presented this view so lucidly in their well-documented article as to engender the hope that it will enlist the interest of many readers in legislatures and courts. There is occasion here only for brief comment on their observation that the California Judicial Council "appears rather an advisory panel to the legislature than an independent power . . . ."54 The characterization is accurate, but it is encouraging to note not only that the legislature has made significant delegations of power to the judicial council, but that it has been so receptive to the council's recommendations as to indicate that there will be like delegations of power whenever the council is ready for them.

In discussing the good, bad, and indifferent ways of the law, I have referred in the main to my own state only because of my familiarity with it. In any event local references from one state may serve to evoke comparable notes from other states. ${ }^{55}$ It is a fair speculation that anywhere in the land we could well intensify our vigil on all aspects of the law.

53 Levin \& Amsterdam, supra note 51, at 36.

54 Id. at 7 n. 36 .

55 Certainly the sister state of New York has a related problem of statutory fetters. In 1912 the New York Board of Consolidation was moved to comment:

The system of regulating details of practice by statutory rules is open to the objections that statutory rules are: (1) subject to distortion by inexperienced legislators and (2) to amendments to suit individual cases; (3) they bind the courts to rigid rules, (4) conduce to contests over minor points of practice, (5) clog the courts with technical questions of statutory construction, and (6) place the responsibility for the administration of justice upon the courts while giving control over it to the legislature.

N.Y. Bd. of Statutory Consolidation, Plan for the Simplification of the Civil Practice in the Courts of the State app. 30 (1912).

New York is still in fetters, though there has been some recent mitigation of statutory constraints. The judicial reorganization of 1962 in New York is designed to reform civil procedure. N.Y. Sess. Laws 1962, chs. 308-18. Some 2,000 sections of the old Civil Practice Act and Rules of Civil Practice have been reduced to about 600 sections in the new Civil Practice Law and Rules. N.Y. Judicial Conference Eighth AnN. ReP. 27 (1963). Procedural statutes adopted thereunder by the legislature will be continuously coordinated with the rules adopted by the New York Judicial Conference. Rules proposed by the judicial conference must be reported to the legislature before February 1st of each year to become operative on the following July 1st, if not disapproved by the legislature. The statutes and rules are organized in such a way that a single publication will provide a unified statement of the regulations governing procedure. The legislature, after consultation with the New York Judicial Conference, determines whether a particular matter should be governed by statute or rule. N.Y. Advisory Comm. on Practice and Procedure, Final Report A-109 to -117 (1961). See also N.Y. Judicinl Conference Ninth AnN. Rep. 13-18 (1964); N.Y. Judicial Conference Eighth Ann. Rep. 26-35 (1963). 
I am mindful in closing that any proposal for a new look at the familiar, particularly one that might lead to a new look in the familiar, is bound to run up against chronic defeatism and sloth and timidity. The defeatists rationalize their own defection from responsibility on the premise that the good old days were as bad as ours, and that we need not bestir ourselves to mend our ways so long as they are merely going from bad to bad. The sloths would not rouse themselves even to such rationalization. The timid may wish to get rid of the bad, but are fearful of any involvement. It would be less than noble to take refuge in such company.

These plain words have been no lute song, but in their way they bespeak constancy to a great lady, even when she is less than her best. She has more than once given us cause to remember that she can live up to her part magnificently when she knows all eyes are upon her. 